\title{
Assessment of Undiscovered Gas Resources of the Fruitland Total Petroleum System, San Juan Basin Province, New Mexico and Colorado, 2020
}

Using a geology-based assessment methodology, the U.S. Geological Survey estimated undiscovered, technically recoverable mean resources of 39 trillion cubic feet of gas within continuous and conventional reservoirs of the Fruitland Total Petroleum System in the San Juan Basin Province, New Mexico and Colorado.

\section{Introduction}

The U.S. Geological Survey (USGS) completed a geology-based assessment of undiscovered, technically recoverable continuous and conventional gas resources in the Pictured Cliffs Sandstone, Fruitland Formation, and overlying Tertiary Period sandstones within the Fruitland Total Petroleum System (TPS) in the San Juan Basin of New Mexico and Colorado. The Fruitland TPS was last assessed in 2002 as part of a broad assessment of oil and gas resources within Jurassic and Cretaceous reservoirs in the San Juan Basin Province (Ridgley and others, 2013). Since that time, additional drilling has been primarily focused in coal beds of the Fruitland Formation and tight-gas reservoirs within the Pictured Cliffs Sandstone (IHS Markit $^{\circledR}, 2019$ ).

\section{Geologic Summary}

The Pictured Cliffs Sandstone and Fruitland Formation represent the last major regressive episode of deposition within the San Juan Basin during the Cretaceous Period. The Pictured Cliffs Sandstone is a marginal marine deposit consisting of very fine to medium-grained sandstone, siltstone, and mudstone. The overlying Fruitland Formation was deposited within nearshore paludal environments and consists of interbedded coal, shale, siltstone, and sandstone. The Fruitland Formation coal beds are the primary source of gas within the Fruitland TPS, although migration of gas from the underlying Lewis Shale into these reservoirs is possible. Minor conventional gas resources are also present within overlying sandstone reservoirs of the Paleocene Ojo Alamo Sandstone and Nacimiento Formation and the Eocene San Jose Formation. Tertiary sandstones in the San Juan Basin are primarily composed of fluvial conglomerates, sandstones, mudstones, and shale (Ridgley and others, 2013).

\section{Total Petroleum System and Assessment Units}

The Fruitland TPS consists of all Cretaceous and Tertiary strata that contain gas sourced from coals of the Cretaceous Period Fruitland Formation. Three continuous assessment units (AUs; fig. 1) were delineated in Cretaceous strata: (1) Pictured Cliffs Continuous Gas AU, (2) Basin Fruitland Coalbed Gas AU, and (3) Northern Fruitland Coalbed Gas AU. The Pictured Cliffs Continuous Gas AU and the Basin Fruitland Coalbed Gas AU were defined based on the areal extents of those named formations in the San Juan Basin. The Northern Fruitland Coalbed Gas AU was defined where artesian overpressure and significant cumulative gas and water production occur within the northern region of the

Fruitland Formation. One conventional AU (Tertiary Conventional Gas AU) was defined for the Tertiary strata and encompasses the areal extent of these sandstones within the San Juan Basin (fig. 1). Key input data used to assess the Fruitland TPS are listed in table 1.

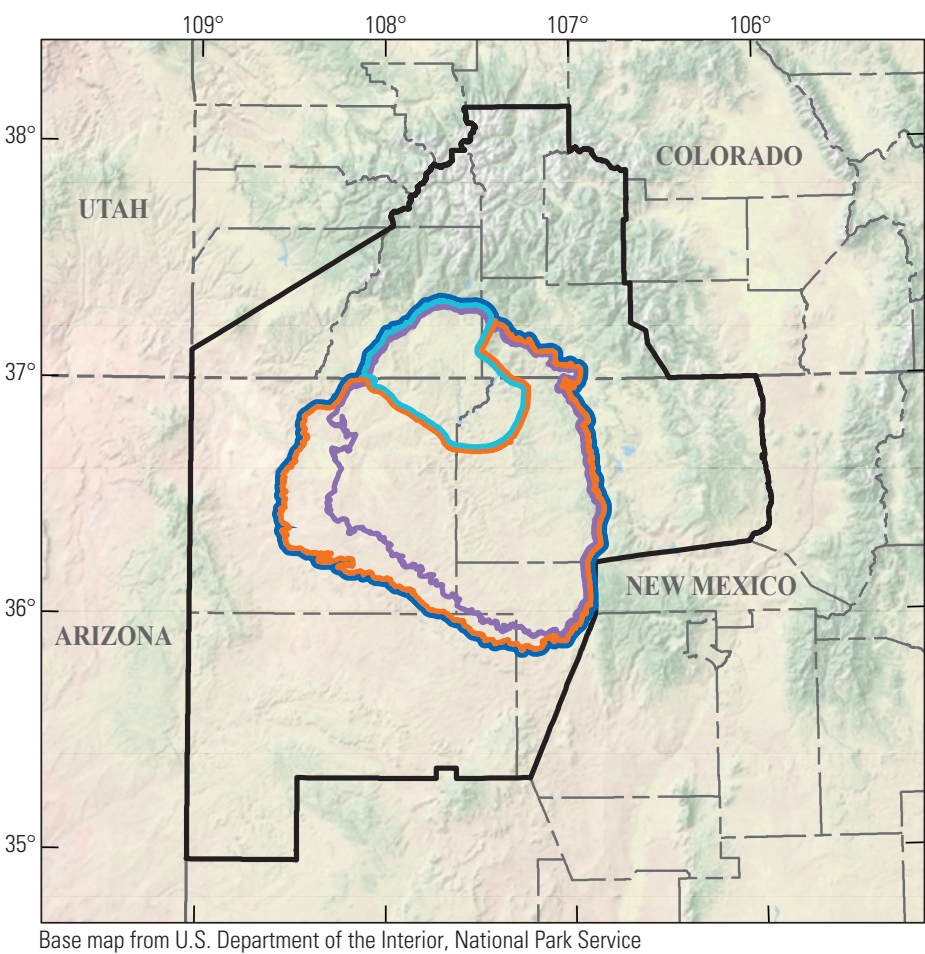

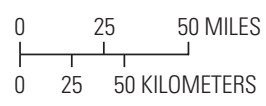

EXPLANATION
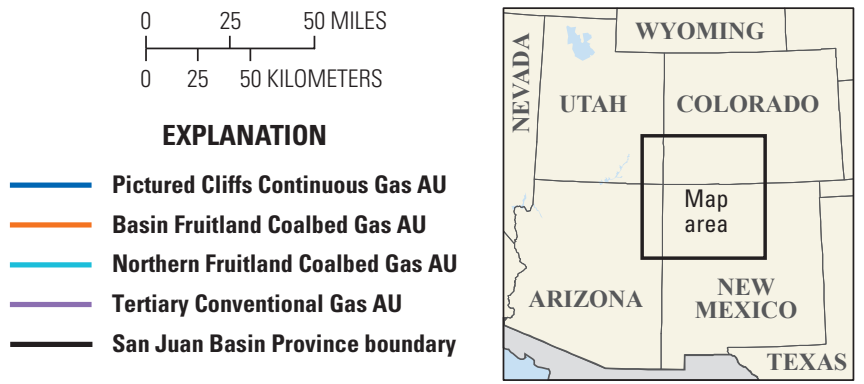

Figure 1. Map showing the San Juan Basin Province in New Mexico and Colorado, the extent of the Pictured Cliffs Continuous Gas Assessment Unit (AU), the extents of the two continuous Fruitland Coalbed Gas AUs, and the extent of the Tertiary Conventional Gas $\mathrm{AU}$ in the Fruitland Total Petroleum System. Adjacent lines indicate a shared boundary at the outermost line. 
Table 1. Key input data for three continuous assessment units (AUs) and one conventional AU in the Fruitland Total Petroleum System of the San Juan Basin, New Mexico and Colorado.

[Well drainage area, success ratio, and estimated ultimate recovery are defined partly using U.S. shale-gas analogs. Shading indicates not applicable. AU, assessment unit; \%, percent; EUR, estimated ultimate recovery (per well); BCFG, billion cubic feet of gas]

\begin{tabular}{|c|c|c|c|c|c|c|c|c|}
\hline \multirow{2}{*}{$\begin{array}{l}\text { Assessment input data- } \\
\text { Continuous AUs }\end{array}$} & \multicolumn{4}{|c|}{ Pictured Cliffs Continuous Gas AU } & \multicolumn{4}{|c|}{ Basin Fruitland Coalbed Gas AU } \\
\hline & Minimum & Mode & Maximum & $\begin{array}{c}\text { Calculated } \\
\text { mean }\end{array}$ & Minimum & Mode & Maximum & $\begin{array}{c}\text { Calculated } \\
\text { mean }\end{array}$ \\
\hline Potential production area of AU (acres) & 100,000 & $2,172,000$ & $4,255,000$ & $2,175,667$ & 10,000 & $1,800,000$ & $3,462,000$ & $1,757,333$ \\
\hline Average drainage area of wells (acres) & 40 & 80 & 160 & 93.3 & 60 & 80 & 160 & 100 \\
\hline Area untested in AU (\%) & 74 & 87 & 94 & 85 & 78 & 89 & 92 & 86.3 \\
\hline Success ratio $(\%)$ & 50 & 70 & 90 & 70 & 50 & 70 & 90 & 70 \\
\hline Average EUR (BCFG) & 0.6 & 1.1 & 1.7 & 1.122 & 0.6 & 1 & 1.5 & 1.019 \\
\hline AU probability & 1.0 & & & & 1.0 & & & \\
\hline \multirow{2}{*}{$\begin{array}{l}\text { Assessment input data- } \\
\text { Continuous AUs }\end{array}$} & \multicolumn{4}{|c|}{ Northern Fruitland Coalbed Gas AU } & \multirow{2}{*}{\multicolumn{4}{|c|}{ For More Information }} \\
\hline & Minimum & Mode & Maximum & $\begin{array}{l}\text { Calculated } \\
\text { mean }\end{array}$ & & & & \\
\hline Potential production area of AU (acres) & 50,000 & 450,000 & 792,100 & 430,700 & \multirow{4}{*}{\multicolumn{4}{|c|}{$\begin{array}{l}\text { Assessment and methodology } \\
\text { information can also be accessed at the } \\
\text { USGS Energy Resources Program website at } \\
\text { https://energy.usgs.gov. }\end{array}$}} \\
\hline Average drainage area of wells (acres) & 60 & 80 & 160 & 100 & & & & \\
\hline Area untested in $\mathrm{AU}(\%)$ & 30 & 50 & 65 & 48.3 & & & & \\
\hline Success ratio $(\%)$ & 80 & 90 & 95 & 88.3 & & & & \\
\hline Average EUR (BCFG) & 4 & 6 & 7 & 6.019 & \multirow{7}{*}{\multicolumn{4}{|c|}{$\begin{array}{l}\text { Fruitland Total Petroleum System } \\
\text { Assessment Team } \\
\text { Kristen R. Marra, Christopher J. Schenk, } \\
\text { Tracey J. Mercier, Heidi M. Leathers-Miller, } \\
\text { Marilyn E. Tennyson, Thomas M. Finn, } \\
\text { Cheryl A. Woodall, Michael E. Brownfield, } \\
\text { Phuong A. Le, and Ronald M. Drake II }\end{array}$}} \\
\hline AU probability & 1.0 & & & & & & & \\
\hline \multirow{2}{*}{$\begin{array}{c}\text { Assessment input data- } \\
\text { Conventional AU }\end{array}$} & \multicolumn{4}{|c|}{ Tertiary Conventional Gas AU } & & & & \\
\hline & Minimum & Mode & Maximum & $\begin{array}{c}\text { Calculated } \\
\text { mean }\end{array}$ & & & & \\
\hline Number of gas fields & 1 & 3 & 5 & 3.0 & & & & \\
\hline Size of gas fields (BCFG) & 3 & 10 & 50 & 11.4 & & & & \\
\hline AU probability & 0.9 & & & & & & & \\
\hline
\end{tabular}

Table 2. Results for three continuous assessment units (AUs) and one conventional AU in the Fruitland Total Petroleum System of the San Juan Basin, New Mexico and Colorado.

[Results shown are fully risked estimates. F95 represents a 95-percent chance of at least the amount tabulated; other fractiles are defined similarly. Shading indicates not applicable. BCFG, billion cubic feet of gas; NGL, natural gas liquids; MMBNGL, million barrels of natural gas liquids; CBG, coal bed gas]

\begin{tabular}{|c|c|c|c|c|c|c|c|c|c|c|}
\hline \multirow{3}{*}{$\begin{array}{l}\text { Total petroleum system and } \\
\text { assessment units (AUs) }\end{array}$} & \multirow{3}{*}{$\begin{array}{c}\text { AU } \\
\text { prob- } \\
\text { ability }\end{array}$} & \multirow{3}{*}{$\begin{array}{c}\text { Accum- } \\
\text { ulation } \\
\text { type }\end{array}$} & \multicolumn{8}{|c|}{ Total undiscovered resources } \\
\hline & & & \multicolumn{4}{|c|}{ Gas (BCFG) } & \multicolumn{4}{|c|}{ NGL (MMBNGL) } \\
\hline & & & F95 & F50 & F5 & Mean & F95 & F50 & F5 & Mean \\
\hline \multicolumn{11}{|c|}{ Fruitland Total Petroleum System } \\
\hline Pictured Cliffs Continuous Gas AU & 1.0 & Gas & 5,056 & 15,340 & 31,188 & 16,365 & 13 & 44 & 103 & 49 \\
\hline Basin Fruitland Coalbed Gas AU & 1.0 & $\mathrm{CBG}$ & 3,331 & 10,730 & 20,449 & 11,156 & 0 & 0 & 0 & 0 \\
\hline Northern Fruitland Coalbed Gas AU & 1.0 & CBG & 4,080 & 10,928 & 20,652 & 11,481 & 0 & 0 & 0 & 0 \\
\hline Total undiscovered continuous resources & & & 12,467 & 36,998 & 72,289 & 39,002 & 13 & 44 & 103 & 49 \\
\hline Tertiary Conventional Gas AU & 0.9 & Gas & 0 & 32 & 55 & 31 & 0 & 0 & 0 & 0 \\
\hline Total undiscovered conventional resources & & & 0 & 32 & 55 & 31 & 0 & 0 & 0 & 0 \\
\hline Total undiscovered resources & & & 12,467 & 37,030 & 72,344 & 39,033 & 13 & 44 & 103 & 49 \\
\hline
\end{tabular}

\section{Undiscovered Resources Summary}

The USGS assessed undiscovered, technically recoverable continuous and conventional gas resources for four AUs within the Fruitland TPS (table 2). Total estimated mean resources are 39,033 billion cubic feet of gas (BCFG), or 39 trillion cubic feet of gas, with an F95-F5 range from 12,467 to 82,061 BCFG and 49 million barrels of natural gas liquids (MMBNGL) with an F95-F5 range from 13 to 103 MMBNGL. Most of the estimated gas resources are within the three continuous AUs of the Pictured Cliffs Sandstone and Fruitland Formation.

\section{References Cited}

IHS Markit $^{\circledR}, 2019$, Enerdeq ${ }^{\mathrm{TM}}$ US well history and production database: Englewood, Colo., IHS Markit, accessed December 2019 at http://www.ihsmarkit.com. [Available from IHS Markit, 15 Inverness Way East, Englewood, CO 80112.]

Ridgley, J.L., Condon, S.M., and Hatch, J.R., 2013, Geology and oil and gas assessment of the Fruitland Total Petroleum System, San Juan Basin, New Mexico and Colorado, chap. 6 of U.S. Geological Survey San Juan Basin Assessment Team, comps., Total petroleum systems and geologic assessment of undiscovered oil and gas resources in the San Juan Basin Province, exclusive of Paleozoic rocks, New Mexico and Colorado: U.S. Geological Survey Data Series 69-F, p. 1-100. 